\title{
Tidal and seasonal influences in dolphin habitat use in a southern Brazilian estuary
}

\author{
Renan Lopes Paitach ${ }^{1,2}$, Paulo César Simões-Lopes ${ }^{1}$, Marta Jussara Cremer ${ }^{2}$ \\ ${ }^{1}$ Laboratory of Aquatic Mammals, Federal University of Santa Catarina - UFSC, P.O. Box 5102, CEP 88040-970, \\ Florianopolis, Santa Catarina, Brazil. \\ (RLP) (Corresponding author) E-mail: renan_ptch@hotmail.com. ORCID-iD: http://orcid.org/0000-0003-2889-8660 \\ (PCS-L) E-mail: lamaqs1@ccb.ufsc.br. ORCID-iD: http://orcid.org/0000-0002-7338-3669 \\ ${ }^{2}$ Laboratory of Coastal Ecosystems, University of Joinville Region - UNIVILLE, P.O. Box 110, CEP 89240-000, \\ São Francisco do Sul, Santa Catarina, Brazil. \\ (MJC) E-mail: mjc2209@yahoo.com.br. ORCID-iD: http://orcid.org/0000-0003-3521-1409
}

\begin{abstract}
Summary: In this study we describe how franciscana and Guiana dolphin habitat use is influenced by tidal cycles and seasonality in Babitonga Bay. The franciscanas use a greater area in winter and a smaller area in summer, but the extent of the area used did not vary with the tide. Guiana dolphins did not change the extent of the area used within seasons or tides. Franciscanas remained closer to the mouth of the bay and the islands during ebb tide, moving to the inner bay areas and closer to the mainland coast during flood tide. Guiana dolphin used areas closer to the mainland coast during the flood tide. Guiana dolphin patterns of movement do not seem to be related to the tidal current. Franciscanas used sandier areas while Guiana dolphins preferred muddy areas, with some seasonal variation. We suggest that these dolphins modify their distributions based on habitat accessibility and prey availability. This study enhances our knowledge of critical habitat characteristics for franciscana and Guiana dolphins, and these factors should be considered when planning local human activities targeting species conservation.
\end{abstract}

Keywords: tide cycles; survey method; franciscana dolphin; Guiana dolphin; critical habitat; Babitonga Bay; SW Atlantic Ocean.

Influencia de las mareas y las estaciones en el uso de hábitat de delfines en un estuario del sur de Brasil

Resumen: En este estudio describimos como el uso del hábitat del delfín franciscana y delfín costero es influenciado por los ciclos de mareas y las estaciones en la bahía Babitonga. Las franciscanas utilizan áreas mayores en invierno y menores en verano, pero el tamaño del área utilizada no varió con las mareas. El área de uso del delfín costero no varió entre estaciones ni con las mareas. Las franciscanas permanecieron más próximas a la boca de la bahía e islas durante la marea baja, moviéndose hacia áreas más internas cercanas al margen del continente durante la marea alta. Del mismo modo, el delfín costero utilizó áreas cercanas al margen del continente durante la marea alta. Los patrones de movimiento del delfín costero no presentaron relación con las corrientes de marea. Las franciscanas utilizaron áreas con más arena mientras que los delfines costeros prefirieron áreas lodosas; esta preferencia varió estacionalmente para ambas especies. Sugerimos que estos delfines modifican su distribución en base a la accesibilidad del hábitat y la disponibilidad de presas. Este estudio aumenta nuestro conocimiento sobre las características del hábitat crítico para la franciscana y el delfín costero, y estos factores deben ser considerados en la planificación de las actividades humanas locales orientadas a la conservación de estas especies.

Palabras clave: ciclos de mareas; método de barrido; delfín franciscana; delfín costero; hábitat crítico; bahía Babitonga; Océano Atlántico SO.

Citation/Como citar este artículo: Paitach P.L., Simões-Lopes P.C., Cremer M.J. 2017. Tidal and seasonal influences in dolphin habitat use in a southern Brazilian estuary. Sci. Mar. 81(1): 49-56. doi: http://dx.doi.org/10.3989/scimar.04495.25A

Editor: D. Oro.

Received: June 20, 2016. Accepted: November 3, 2016. Published: January 23, 2017.

Copyright: () 2017 CSIC. This is an open-access article distributed under the terms of the Creative Commons Attribution (CC-by) Spain 3.0 License. 


\section{INTRODUCTION}

Estuaries are particularly influenced by tidal cycles, which include periodic variations in depth, direction, current speed, salinity, temperature and availability of flooded areas (McLusky and Elliott 2004). Fish and crustaceans often modify their distributions and behaviours in response to variation in these environmental factors (Reis-Filho et al. 2011). These tidal migrations involve the movement of large numbers of species between locations synchronously with the tidal cycle (Gibson 2003). Top predators should be able to take advantage of these temporal changes in the aquatic environment to optimize the capture of prey (Lin et al. 2013).

Identification of patterns of habitat use is key to our understanding of many ecological aspects of species biology, such as population trends and social dynamics (Krebs 2008). This knowledge is crucial for creating strategies that may minimize or mitigate human impacts upon natural environments (Hastie et al. 2004). Several studies have recognized the influence of tide on cetacean species distributions, behaviour and habitat use (e.g. Shane 1990, Bordino 2002), but few studies have specifically aimed to describe these effects in detail (e.g. Mendes et al. 2002, Fury and Harrison 2011, Lin et al. 2013). Hypotheses from optimal foraging theory (Perry and Pianka 1997) suggest that dolphins have lower spatial requirements in terms of area used when resource availability is higher.

The franciscana dolphin, Pontoporia blainvillei (Gervais and d'Orbigny 1844), occurs in the coastal waters of eastern South America between the Brazilian state of Espírito Santo $\left(18^{\circ} 25^{\prime} \mathrm{S}\right)$ and the Argentine province of Chubut (42³5'S) (Siciliano 1994, Crespo et al. 1998). They are the most threatened small cetacean in the southwest Atlantic Ocean. They are classified as "critically endangered" in Brazil (MMA 2014) and "vulnerable" on the IUCN Red List of Threatened Species (Reeves et al. 2012), and are on the List of Species Threatened with Extinction in Santa Catarina (CONSEMA 2011). There is some evidence that the influence of tidal cycles on species movement patterns are driven by trophic factors (Bordino 2002). The highest frequency of franciscana feeding behaviour in Anegada Bay, Argentina, has been observed at high tide (Bordino et al. 1999). However, knowledge of the behavioural ecology of the species is still limited because observation in its natural environment is difficult due to its small body size, discreet behaviour and cryptic colouration (Cremer and Simões-Lopes 2008).

The Guiana dolphin, Sotalia guianensis (Van Bénéden 1864), is strongly associated with estuarine environments, protected bays and river mouths (Borobia et al. 1991). It is distributed along the tropical and subtropical coasts of South and Central America, from Nicaragua to Florianopolis, Santa Catarina, southern Brazil (Simões-Lopes 1988, Carr and Bonde 2000). The IUCN classifies this species as "poorly known" due to lack of population studies and information on threats to populations (Secchi 2012). It is classified as "vulnerable" in Brazil (MMA 2014) and "endangered" in Santa Catarina state (CONSEMA 2011), where there are only two stocks (Babitonga Bay: Cremer et al. 2011 and North Bay: Simões-Lopes 1988). Guiana dolphins seem to exhibit strong site fidelity, and tend not to move very far from population habitat areas (Wedekin et al. 2007, Hardt et al. 2010). In open coastal environments, Araújo et al. (2007) found no significant effects of tidal cycles on area utilization or variation in behaviour of the Guiana dolphin, while Azevedo et al. (2007) did find tidal effects in an estuarine environment.

Babitonga Bay is the only location in the world with resident sympatric populations of franciscana and Guiana dolphins throughout the year (Cremer and Simões-Lopes 2008, Hardt et al. 2010). Previous studies found heterogeneous distributions with spatial overlap between species, and estimated site abundances of about 50 franciscanas and 200 Guiana dolphins (Cremer and Simões-Lopes 2008, Cremer et al. 2011). However, the future of these cetacean populations and ecosystem function as a whole may be compromised due to increasing human impacts, such as dumping of domestic and industrial effluents, intense urbanization of the cities that surround the bay, and new harbour enterprises in the region (Cremer 2007, Paitach 2015). This study sought to understand the factors that influence habitat use in these species, and may serve as a guide for planning human activities in Babitonga Bay.

\section{MATERIALS AND METHODS}

\section{Study area}

Babitonga Bay $\left(26^{\circ} 02^{\prime}-26^{\circ} 28^{\prime} \mathrm{S}\right.$ and $48^{\circ} 28^{\prime}$ $48^{\circ} 50^{\prime} \mathrm{W}$ ) has an area of approximately $160 \mathrm{~km}^{2}$ in Santa Catarina state in southern Brazil (Fig. 1). Its river basin covers an area of $1560 \mathrm{~km}^{2}$ and extends throughout six municipalities. The bay area has 83 islands as well as ledges and tidal flats, and receives input from several rivers. The bay is considered an estuary with homogeneous physicochemical conditions, so there are no significant variations in salinity and temperature on a spatial scale. These variables are mainly affected on time scales due to tidal conditions (salinity) and seasons (temperature) (IBAMA 1998). The area has a semidiurnal regime of micro-tides, i.e. two daily, welldefined cycles of ebb and flow during spring tides, with tide reaching a maximum amplitude of $2.3 \mathrm{~m}$. There is a dominance of flood tide, with amplification in the innermost areas through effects of narrowing in the main channel (Truccolo and Schettini 1999). The main channel in the northeast direction is approximately $3.8 \mathrm{~km}$ wide, with depths up to $28 \mathrm{~m}$, and this channel is the only connection to the open sea.

\section{Data collection}

Sampling was carried out from February 2004 to August 2014 (154 days), following an adapted survey method (from Mann 1999) that aims to get a "picture" of the distribution of populations by covering the entire study area homogeneously in the shortest time possible. Two preestablished routes were covered by boat with varying frequencies over the years. From 2004 to 


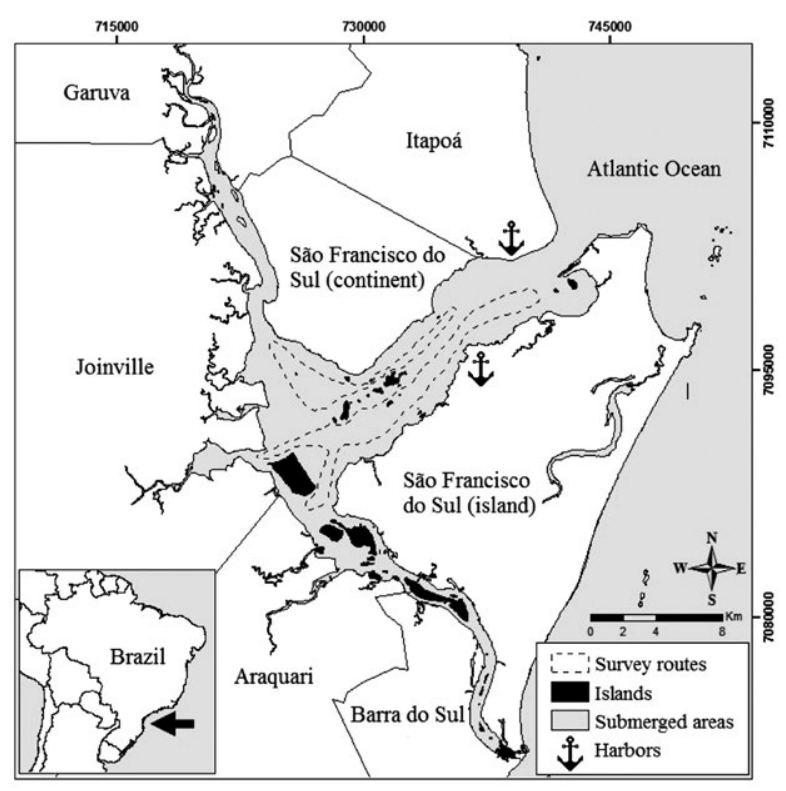

Fig. 1. - Map of Babitonga Bay in southern Brazil. Dolphin survey routes are indicated with dotted lines.

2009 , between one and four monthly surveys were conducted, and the routes were followed in sequence. We did not survey the area in 2010. Beginning in March 2011, surveys were performed at least bi-weekly, with the two routes taken simultaneously. During the surveys the boat remained at a constant speed of approximately $20 \mathrm{~km} \mathrm{~h}^{-1}$. No surveys were carried out if sea conditions were above 1 on the Beaufort scale and if the conditions become inadequate throughout a survey, the circuit was interrupted and the data collected were considered.

Groups of dolphins were searched for visually, sometimes using Bushnell $7 \times 50$ binoculars. When dolphins were sighted, the time, geographical position and number of individuals were recorded. We identified tidal conditions for each record using the tide tables published by the Directorate of Hydrography and Navigation of the Brazilian Navy for the port of São Francisco do Sul. The following tidal categories were adopted: early flood, late flood, early ebb and late ebb. Each tide period was divided in half due to the timing of tides, with the first half considered as 'early' and the second half considered as 'late' (for both flood and ebb tides). The total sampling effort was $419 \mathrm{~h}$. The number of sampling hours in each tidal stage was as follows: $141 \mathrm{~h}$ in early flood; $113 \mathrm{~h}$ in late flood; 70 $\mathrm{h}$ in early ebb; and $95 \mathrm{~h}$ in late ebb. The number of sampling hours in each season was as follows: $129 \mathrm{~h}$ in the autumn; $130 \mathrm{~h}$ in the winter; $75 \mathrm{~h}$ in the spring; and $85 \mathrm{~h}$ in the summer.

\section{Data analysis}

Different metrics were adopted to verify variation in habitat use by franciscana and Guiana dolphins in relation to tidal cycles and seasons. We first observed changes in the size of home range and core areas. The geographical positions of dolphin groups were record- ed using a geographic information system. The areas were estimated using the fixed kernel method, which takes the intensity of use in the area into account (Laver 2005). We used the "Animal Movement Analyst" extension in ArcGIS 3.2 (Hooge and Eichenlaub 1997). The bandwidth of the areas was determined by the least squares cross-validation method (Powell 2000). Estimating the area with $95 \%$ of the recorded geographical locations allowed us to estimate habitat use area (home range) excluding outliers, and considering the density of $50 \%$ of the records identified the core areas. The kernel method is optimized for analysis of individuals, but in this study we chose to use the method as a group approach, with the goal of highlighting general patterns (Ingram and Rogan 2002). The portions of areas that overlapped the land areas were excluded with the "clip tool', so the areas were recalculated in ArcGIS 10.3.

Records from each sampled year were grouped by season and tidal state and analysed separately. Only years with more than five groups of franciscana or Guiana dolphin records per season and tidal state were used. The data were tested for normality and homogeneity of variances, and an ANOVA was used to test for the effect of season (spring, summer, autumn and winter) and tidal state (early flood, late flood, early ebb and late ebb) on variation in the home range and core areas of franciscana and Guiana dolphins. The test was run with a confidence interval of $95 \%$ (Zar 1999).

We then analysed depth, bottom substrate and $\mathrm{Eu}-$ clidean distances from the islands, the mainland and the mouth of the bay for each dolphin group using ArcGIS 10.3. The distances of the islands and the mainland were analysed separately because they represent different habitat features. While the islands are mostly surrounded by rocky headlands, the estuarine mainland is characterized by sandy-muddy beaches and mangroves. The bottom substrate was rated according to Vieira et al. (2008) as one of the following types: sand, sand with mud, mud with sand, and mud.

Pearson correlation results indicated that numerical environmental variables were not correlated ( $p>0.05)$. We used two-way ANOVA to test for effects of season and tidal state on variation in depth and distance from the islands, mainland and mouth of the bay, as well as interactions between main factors (tide and seasonality). We used ANOVA to test for effects even when the data barely met assumptions of normality and homogeneity of variances, but with a $99 \%$ confidence interval to minimize type I errors and increase the power of the analysis (Underwood 1981). We used a chi-square test with a $95 \%$ confidence interval to test for differences in bottom substrate used by dolphins between seasons and tidal states (Zar 1999). All statistical analyses were conducted in $\mathrm{R}$ version 3.2.3 ( $\mathrm{R}$ Development Core Team 2014).

\section{RESULTS}

A total of 950 sightings were recorded, in which 327 were groups of franciscanas and 623 were groups of Guiana dolphins, including groups that were counted more than once. No mixed species groups were found. 
Table 1. - Mean and standard deviation $\left(\mathrm{km}^{2}\right)$ of home range $(95 \%)$ and core area $(50 \%)$ of use for Pontoporia blainvillei and Sotalia guianensis in Babitonga Bay (February 2004 - August 2014). Estimation was by the fixed kernel method with least squares crossvalidation, and ANOVA testing for effects of tidal stage and season (*, significant values).

\begin{tabular}{lcccc}
\hline & \multicolumn{2}{c}{ Pontoporia blainvillei } & \multicolumn{2}{c}{ Sotalia guianensis } \\
& Kernel 95\% & Kernel 50\% & Kernel 95\% & Kernel 50\% \\
\hline Early flood & $15.1 \pm 10.1$ & $3 \pm 2.2$ & $50.4 \pm 15.2$ & $8.8 \pm 4.4$ \\
Late flood & $16.8 \pm 13.5$ & $3.4 \pm 2.3$ & $42.4 \pm 20.1$ & $8.8 \pm 7.4$ \\
Early ebb & $18.2 \pm 14.6$ & $3.1 \pm 2.7$ & $38.2 \pm 13.6$ & $8.2 \pm 6.9$ \\
Late ebb & $15.5 \pm 10.2$ & $3.2 \pm 2.4$ & $38.5 \pm 21.4$ & $7.5 \pm 4.5$ \\
F tide & 0.079 & 0.040 & 0.864 & 0.21 \\
P tide & 0.97 & 0.988 & 0.471 & 0.888 \\
Autumn & $17.1 \pm 13.1$ & $3.6 \pm 4.4$ & $46 \pm 15.1$ & $9.3 \pm 4.9$ \\
Winter & $24.3 \pm 14.3$ & $5 \pm 3.2$ & $42.8 \pm 16.9$ & $7 \pm 3.6$ \\
Spring & $12.6 \pm 6.5$ & $3.2 \pm 2.8$ & $41.1 \pm 17$ & $7.5 \pm 5.4$ \\
Summer & $6.3 \pm 6.8$ & $1.4 \pm 1.7$ & $37.3 \pm 21.5$ & $9.1 \pm 9.4$ \\
F season & 3.776 & 1.847 & 0.559 & 0.222 \\
P season & $0.030 *$ & 0.176 & 0.647 & 0.88 \\
\hline
\end{tabular}

Table 2. - Mean and standard deviation (metres) of habitat use metrics for Pontoporia blainvillei in Babitonga Bay (February 2004 - August 2014) with bi-factorial ANOVA results testing for effects of tidal stage and season (*, significant values).

\begin{tabular}{lcccc}
\hline & $\begin{array}{c}\text { Average } \\
\text { depth }\end{array}$ & $\begin{array}{c}\text { Distance } \\
\text { from islands }\end{array}$ & $\begin{array}{c}\text { Distance } \\
\text { from continent }\end{array}$ & $\begin{array}{c}\text { Distance } \\
\text { from mouth }\end{array}$ \\
\hline Early flood & $6.3 \pm 2.1$ & $744 \pm 441$ & $958 \pm 356$ & $13085 \pm 1899$ \\
Late flood & $5.8 \pm 2.1$ & $885 \pm 469$ & $895 \pm 280$ & $13523 \pm 2039$ \\
Early ebb & $5.6 \pm 2.1$ & $813 \pm 486$ & $1023 \pm 378$ & $12744 \pm 2251$ \\
Late ebb & $6.7 \pm 2.7$ & $638 \pm 426$ & $1119 \pm 360$ & $11892 \pm 1858$ \\
F tide & 3.572 & 7.713 & 6.191 & 9.562 \\
P tide & 0.014 & $0.003 *$ & $<0.001^{*}$ & $<0.001^{*}$ \\
Autumn & $6.2 \pm 2.2$ & $812 \pm 481$ & $987 \pm 333$ & $13229 \pm 2070$ \\
Winter & $6.2 \pm 2.5$ & $828 \pm 508$ & $1025 \pm 382$ & $12209 \pm 2292$ \\
Spring & $6.4 \pm 2.2$ & $681 \pm 343$ & $896 \pm 335$ & $12999 \pm 1819$ \\
Summer & $5.9 \pm 2.3$ & $629 \pm 375$ & $1039 \pm 341$ & $13153 \pm 1515$ \\
F season & 0.724 & 3.013 & 1.287 & 5.576 \\
P season & 0.538 & 0.03 & 0.278 & $<0.001 *$ \\
F (tidexseason) & 1.601 & 6.018 & 2.315 & 1.014 \\
P (tidexseason) & 0.113 & $<0.001 *$ & 0.015 & 0.428 \\
\hline
\end{tabular}

Area use for franciscanas was higher in winter and lower in summer $(\mathrm{F}=3.776, \mathrm{P}=0.03$, Table 1$)$, but did not change in relation to tidal cycles $(\mathrm{F}=0.079, \mathrm{P}=0.97)$. The size of core area of franciscanas was not affected by the main factors analysed (season: $\mathrm{F}=1.847, \mathrm{P}=0.176$; tide: $\mathrm{F}=12: 04, \mathrm{P}=0.988)$. Guiana dolphin home range did not change with season $(\mathrm{F}=0.559, \mathrm{P}=0.647)$ or tide $(\mathrm{F}=0.864, \mathrm{P}=0.471)$. The core area of use was also not affected by these factors (stations: $\mathrm{F}=0.21, \mathrm{P}=0.888$; tide: $\mathrm{F}=0.222, \mathrm{P}=0.88$ ).

At the end of ebb tide, franciscanas remained closer to the bay mouth and islands, environments dominated by rocky shore (Table 2). At the end of the flood tide,
Table 3. - Mean and standard deviation (m) of habitat use metrics for Sotalia guianensis in Babitonga Bay (February 2004 - August 2014) with bi-factorial ANOVA results testing for effects of tidal stage and season (*, significant values).

\begin{tabular}{lcccc}
\hline & $\begin{array}{c}\text { Average } \\
\text { depth }\end{array}$ & $\begin{array}{c}\text { Distance } \\
\text { from islands }\end{array}$ & $\begin{array}{c}\text { Distance from } \\
\text { continent }\end{array}$ & $\begin{array}{c}\text { Distance } \\
\text { from mouth }\end{array}$ \\
\hline Early flood & $5.3 \pm 3.1$ & $903 \pm 592$ & $1303 \pm 606$ & $12678 \pm 2735$ \\
Late flood & $5.4 \pm 2.9$ & $1039 \pm 650$ & $1303 \pm 574$ & $12362 \pm 2622$ \\
Early ebb & $4.4 \pm 2.4$ & $1084 \pm 598$ & $1318 \pm 623$ & $13703 \pm 2578$ \\
Late ebb & $4.9 \pm 2.6$ & $954 \pm 610$ & $1521 \pm 599$ & $12308 \pm 2290$ \\
F (tide) & 3.004 & 2.743 & 4.636 & 6.283 \\
P (tide) & 0.029 & 0.042 & $0.003 *$ & $<0.001 *$ \\
Autumn & $5.3 \pm 2.6$ & $1008 \pm 579$ & $1332 \pm 569$ & $12693 \pm 2551$ \\
Winter & $5.3 \pm 3$ & $991 \pm 605$ & $1304 \pm 584$ & $12368 \pm 2619$ \\
Spring & $5 \pm 3.1$ & $828 \pm 648$ & $1350 \pm 651$ & $12624 \pm 2657$ \\
Summer & $4.5 \pm 2.5$ & $1047 \pm 644$ & $1473 \pm 635$ & $13153 \pm 2690$ \\
F (season) & 2.944 & 2.562 & 1.956 & 2.507 \\
P (season) & 0.032 & 0.053 & 0.119 & 0.058 \\
F (tidexseason) & 1.296 & 2.472 & 2.577 & 2.125 \\
P (tidexseason) & 0.235 & $0.008 *$ & $0.006 *$ & 0.025 \\
\hline
\end{tabular}

franciscanas shifted with the current in favour of inner areas of the bay and approached the edge of the continent; these environments are dominated by mangrove and muddy beaches. Franciscanas were closer to the bay mouth in the winters, and in the innermost bay areas in the summers $(\mathrm{F}=5.576, \mathrm{P}<0.001)$. Area depth did not change in relation to tidal cycles $(\mathrm{F}=3.572$, $\mathrm{P}=0.014)$ or seasonality $(\mathrm{F}=0.724, \mathrm{P}=0538)$. The distance that the animals remained from the islands did not change due to season alone $(\mathrm{F}=7.713, \mathrm{P}=0.003)$, but there were joint effects of season and tide $(\mathrm{F}=6.018$, $\mathrm{P}<0.001)$. This significant interaction indicated that tide may influence franciscana habitat use differently between seasons.

There were no differences in substrate use by franciscanas at different tidal stages $\left(\chi^{2}=4.106, \mathrm{P}=0662\right)$, but we did detect differences between seasons $\left(\chi^{2}=17.995\right.$, $\mathrm{P}=0.006)$. In summer they predominantly used areas with sandy substrate $(92 \%)$, and the species was not recorded in areas with only mud substrate (Fig. 2).

The Guiana dolphin used areas closer to the continental shore during the flood tide in mangroves and sandy-muddy beaches, and moved away at the end of ebb tide (Table 3 ). The distance from the estuary mouth ranged between tidal states $(\mathrm{F}=6.283, \mathrm{P}<0.001)$. However, we were not able to identify a pattern of movement in relation to the tidal current. The depth and distance from islands did not vary due to tidal cycles (depth: $\mathrm{F}=3.004, \mathrm{P}=0.029$; distance of islands: $\mathrm{F}=2.743, \mathrm{P}=0.042$ ) or seasonality (depth: $\mathrm{F}=2.944$, $\mathrm{P}=0.032$; distance of islands: $\mathrm{F}=2.562, \mathrm{P}=0.053$ ) alone.
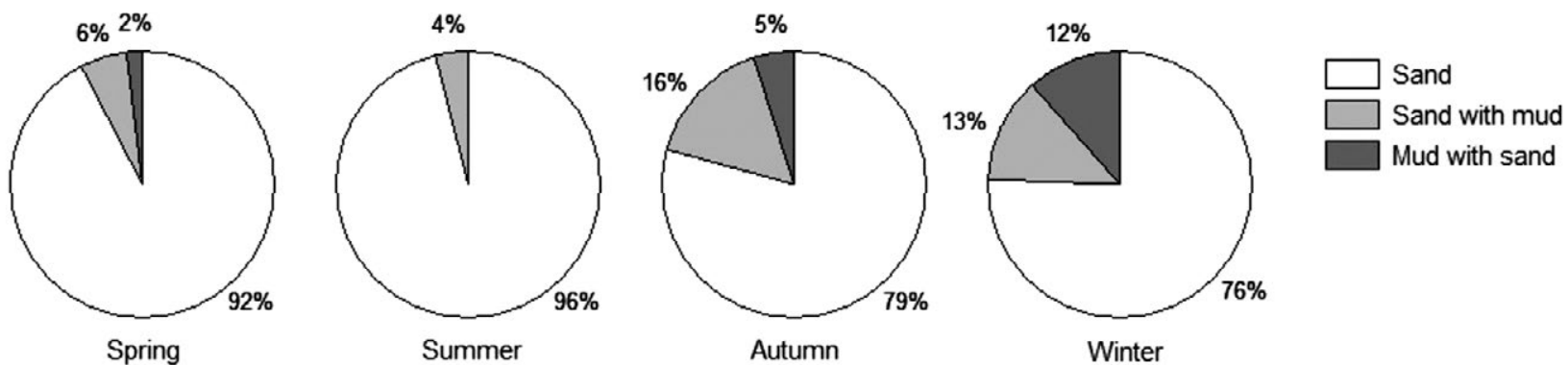

Fig. 2. - Variation in bottom substrate of the areas used by Pontoporia blainvillei per season in Babitonga Bay (February 2004 - August 2014). 

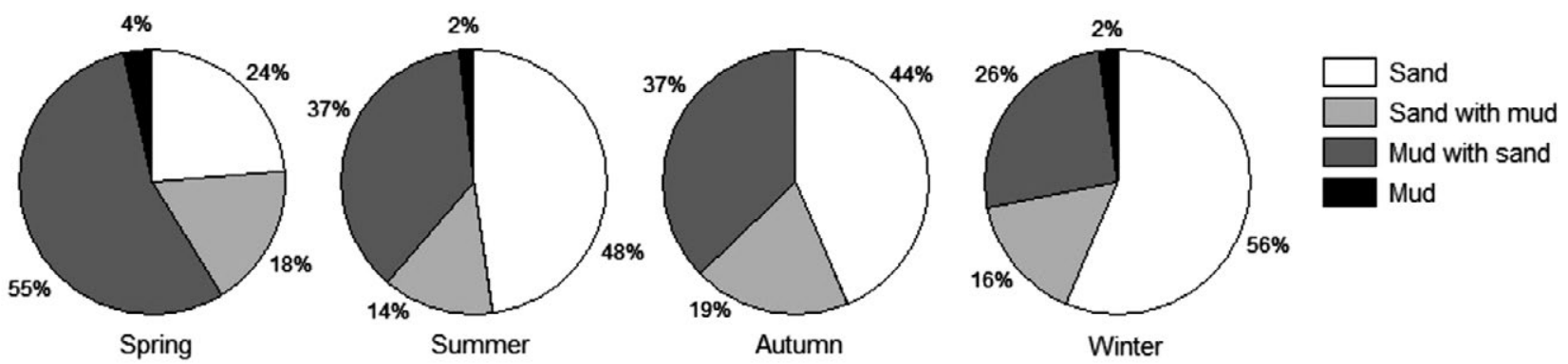

Fig. 3. - Variation in bottom substrate of the areas used by Sotalia guianensis per season in Babitonga Bay (February 2004 - August 2014).

But when the joint effect of tide and season was considered, there was variation in the distance to the islands $(\mathrm{F}=2.472, \mathrm{P}=0.008)$ and continental shores $(\mathrm{F}=2.577$, $\mathrm{P}=0.006)$. This finding shows that, as in the franciscana, tide can influence the habitat use of the Guiana dolphin differently between seasons.

As in the franciscanas, the bottom substrate type used by Guiana dolphins did not differ with the tidal cycle $\left(\chi^{2}=10.651, \mathrm{P}=0.300\right)$. There was seasonal variation in substrate use $\left(\chi^{2}=39.727, \mathrm{P}<0.001\right)$, with Guiana dolphins predominantly using sand in winter (56\%) and mud with sand in the spring (55\%) (Fig. 3).

\section{DISCUSSION}

The habitat use patterns of franciscana and Guiana dolphins in Babitonga Bay varied seasonally and by daily tidal cycles, but in different ways. We suggest that the observed results probably reflect the availability of prey for the dolphins. Several studies relate distribution, habitat use and behaviour of cetaceans with physical environmental parameters (e.g. Ingram and Rogan 2002, Azevedo et al. 2007). However, studies are unanimous in recognizing that these are indirect measures because they primarily influence the distribution of prey, which consequently affects the spatial and behavioural patterns of predators (Hastie et al. 2004). In a study by Ijsseldijk et al. (2015), the authors evaluated the influence of different tidal covariates such as salinity and temperature on habitat use by Phocoena phocoena. Salinity was identified as the most important factor, but according to the authors this is an indirect measure because it is tidal patterns that cause variation in salinity (Ijsseldijk et al. 2015).

The effects of the tide on dolphin spatial patterns are extremely variable. In Hong Kong, for example, Souza chinensis is mostly seen during low tide (Parsons 1998), while in the Moray Firth, Scotland, Tursiops truncatus sightings are most common during the flood tide (Mendes et al. 2002). The latter is similar in behaviour to T. aduncus in the estuaries of the Clarence and Richmond rivers in Australia, where dolphins are also sighted more frequently in flood tide (Fury and Harrison 2011).

Using methods of acoustic detection, Lin et al. (2013) found that $S$. chinensis are more often found at the entrance of the Xin Huwei estuary in Taiwan at high tide, while in Lundy Island, $19 \mathrm{~km}$ from the coast of England, most acoustic detection of $P$. phocoena occurred during the ebb tide (Squires et al. 2014). In southwest Britain, the foraging behaviour of $P$. phocoena is more common at the peak of high tide (Goodwin 2008), while in a nearby shallow coastal area of Cardigan Bay, United Kingdom, foraging is related to the flood period (De Boer et al. 2014). Different populations of the same species may even have different habitat use patterns in relation to tidal cycles (e.g. Parsons 1998, Lin et al. 2013). Thus, it is possible that the characteristics of each habitat determine how the tidal cycles influence the environment and, consequently, how dolphins use the habitat (Lin et al. 2013).

The franciscanas used larger areas in winter and smaller areas in summer. This pattern corresponds to the hypothesis that individuals should be more dispersed when prey availability is lower, and fish abundance in estuaries tends to be higher in warmer seasons due to juvenile recruitment (Gratwicke and Speight 2005). This correlation between distribution and food availability was also verified in a seasonal analysis by Cremer (2007) with the same population of franciscanas. The Guiana dolphins, on the other hand, did not demonstrate these patterns. In North Bay, DauraJorge et al. (2004) observed that the Guiana dolphins tend to move more in the winter. On the coast of São Paulo, Louzada (2014) did not observe behavioural differences of the Guiana dolphins throughout the year, although diet and food availability varied seasonally.

The estuarine fish fauna is strongly influenced by tidal cycles (Reis-Filho et al. 2011). At low tide there is a decrease in habitat and increased population density of fish (the main prey of dolphins), and this increase in resource availability may result in a lower spatial requirement for the predators (Reis-Filho et al. 2011). Contrary to this expectation, we found no differences in area of use of Babitonga Bay franciscanas and Guiana dolphins between tidal cycles. However, it is possible that tidal cycle may influence the accessibility of prey in different ways, affecting other aspects of habitat use of the dolphins.

Franciscanas approached the islands at the end of ebb tide, while Guiana dolphins were affected by tidal conditions differently between seasons. The central region of Babitonga Bay has the greatest concentration of islands and a strong convergence of currents, causing an accumulation of nutrients. This attracts fish and leads this area to be the primary zone of occurrence for franciscanas and Guiana dolphins (Cremer and Simões-Lopes 2008, Cremer et al. 2011). Moreover, 
the islands may act as a natural barrier aiding dolphin hunting, since rocks are a favourable feature for grouping and capturing shoals. The fact that the Guiana dolphin approaches the islands in different tidal conditions throughout the seasons may also be a strategy to capture seasonally occurring prey species. The slope of some areas can also function as a barrier and can be an important variable for many species (e.g. Ingram and Rogan 2002). In North Bay, the estuarine dolphin showed a clear preference for areas with the greatest slope (Wedekin et al. 2010). Although this variable was not considered in this study, we note that the slope is not very steep in Babitonga Bay but tends to be stronger near the islands (Vieira et al. 2008).

Guiana and franciscana dolphins used areas closer to the continental shore at the end of the flood tide. This is the period when tidal flats overflow, causing the fish to migrate to these important feeding areas (Reis-Filho et al. 2011). Dolphins may use these areas opportunistically, as fish are more vulnerable to predation in these locations (Reis-Filho et al. 2011). The use of shallow areas as a strategy to maximize fish capture has already been observed for Guiana dolphins (Souto 2006). In this study, Guiana dolphins moved towards the shore mainly in the flood tide, and more intensely in winter. This behaviour may be due to mullet predation (Mugilidae). These fish have pelagic habits and move in and out of estuaries, staying close to intertidal areas which are their feeding sites (Harrison 2002). The Mugil genus is the most important for the Guiana dolphin diet in Babitonga Bay (Paitach 2015). Similarly, Scott et al. (1990) observed that bottlenose dolphins (T. truncatus) in Florida follow the movement of Mugil cephalus (an important prey species) towards shallow water at high tide, returning to deeper waters at low tide.

Franciscanas moved towards the mouth of the bay during ebb tide and in the opposite direction during flood tide, following the flow of current. This is similar to what occurs in the Anegada Bay (Bordino 2002). Movements in favour of the current may be associated with mechanical drag, resulting in greater travel speed and lower energy consumption (Bordino 2002). This movement may also be related to hunting strategies (Shane 1990). On the other hand, the Guiana dolphins did not show a well-defined pattern in relation to the tidal currents, using inner areas in the early ebb stage and remaining near the mouth of the bay in the late flood stage. A similar pattern was observed for Guiana dolphins in Pontal Bay in Bahia, Brazil, where they moved towards the bay mouth during flood tide (Santos et al. 2010). Although the counter-current foraging strategy has already been described for T. truncatus (Shane 1990), apparently movement following the direction of the current is most common (e.g. Bordino 2002, Mendes et al. 2002, Fury and Harrison 2011).

The franciscanas mainly used areas with a sandy bottom, while the Guiana dolphins used areas with mud more frequently. The franciscana is a species that occurs mainly in the coastal region, outside bays, where the sand substrate is predominant, and the Babitonga Bay franciscana population is the only known species that resides year-round in estuarine environ- ment (Cremer and Simões-Lopes 2008). The Guiana dolphin is strongly associated with estuarine environments in southeastern and southern Brazil (Borobia et al. 1991), and prefers areas with mud substrate (Lodi 2003). Both species vary in use of areas seasonally in association with bottom substrate. This probably occurs due to changes in the composition and abundance of the prey community throughout the year (Gratwicke and Speight 2005).

Twenty-one teleosts were identified in the diet of Babitonga Bay franciscanas, and 28 in Guiana dolphins (Cremer et al. 2012, Paitach 2015). The Cangoá, Stellifer rastrifer (Sciaenidae), was the prey of greatest importance in the franciscana diet, particularly in subadults (Paitach 2015). This is a benthopelagic species, remaining in the water column near the bottom and mainly associated with sandy or muddy substrate (Andrade-Tubino et al. 2008). Although Mugil curema (Mugilidae) was the most important species in the Guiana dolphin diet, there is a degree of seasonal variation in diet, and in cold months (autumn and winter) the Cangoá becomes important (Paitach 2015). Citharichthys spilopterus (Paralichthyidae) was the prey species of greatest importance for subadult Guiana dolphins (Paitach 2015), which are strongly associated with muddy substrate (Robins and Ray 1986).

Acoustic monitoring can be an important tool for understanding patterns of habitat use for dolphins and their prey in waters with poor visibility, such as estuaries (Mellinger et al. 2007). Several fish species become more active at night, and dolphins may use the habitat differently over nictemeral cycles. Acoustic monitoring is the only method allowing such observations, as it is not possible to visually monitor the dolphins overnight (Lin et al. 2013).

The most effective measures for dolphin conservation will probably involve ecological approaches that consider the factors influencing species habitat choices and predator-prey dynamics (Dunning et al. 2006). Our results provide novel information on patterns of habitat use by franciscana and Guiana dolphins in association with tidal cycles and seasonality in Babitonga Bay. We conclude that these dolphins probably adapt their distributions based on habitat accessibility and availability of prey, and suggest the implementation of conservation measures that take these factors into consideration.

\section{ACKNOWLEDGEMENTS}

The study was carried out within the framework of the Toninhas Project/UNIVILLE funded by Petrobras, through Programa Petrobras Ambiental. We thank the staff of Projeto Toninhas for executive management and assistance in the field. We thank the Fundo de Apoio a Pesquisa - FAP/UNIVILLE, which enabled this work. The first author thanks the Coordenação de Aperfeiçoamento de Pessoal de Nível Superior (Capes) for granting scholarships for part of the project period. We wish to thank Jennifer A. Breaux for language review. We also thank the two anonymous reviewers for their important contributions to the manuscript. 


\section{REFERENCES}

Andrade-Tubino M.F., Ribeiro A.L.R., Vianna M. 2008. Organização espaço-temporal das ictiocenoses demersais nos ecossistemas estuarinos brasileiros: uma síntese. Oecol. Bras. 12: 640-661.

http://dx.doi.org/10.4257/oeco.2008.1204.05

Araújo J.P., Araújo M.E., Souto A., et al. 2007. The influence of seasonality, tide and time of activities on the behaviour of Sotalia guianensis (Van Bénéden) (Cetacea, Delphinidae) in Pernambuco, Brazil. Rev. Bras. Zool. 24: 1122-1130. http://dx.doi.org/10.1590/S0101-81752007000400032

Azevedo A.F., Oliveira A.M., Viana S.C. et al. 2007. Habitat use by marine tucuxis (Sotalia guianensis) (Cetacea: Delphinidae) in Guanabara Bay, south-eastern Brazil. J. Mar. Biol. Assoc. 87: 201205

http://dx.doi.org/10.1017/S0025315407054422

Bordino P. 2002. Movement pattern of franciscana dolphins (Pontoporia blainivillei) in Bahia Anegada, Argentina. Lat. Am. J. Aquat. Mamm. 1: 71-76. http://dx.doi.org/10.5597/lajam00011

Bordino P., Thompson G., Iñiguez M. 1999. Ecology and behaviour of the franciscana (Pontoporia blainvillei) in Bahía Anegada, Argentina. J. Cetacean Res. Manag. Cambridge, 1: 213-222.

Borobia M., Siciliano S., Lodi L. et al. 1991. Distribution of the South American dolphins Sotalia fluviatilis. Can. J. Zool. Ottawa 69: 1025-1039. http://dx.doi.org/10.1139/z91-148

Carr T., Bonde R.K. 2000. Tucuxi (Sotalia fluviatilis) occurs in Nicaragua, $800 \mathrm{~km}$ of its previously known range. Mar. Mamm. Sci. 16: 447-452. http://dx.doi.org/10.1111/j.1748-7692.2000.tb00936.x

CONSEMA - Conselho Estadual do Meio Ambiente. 2011. Resolução ${ }^{\circ} 002$, de 6 de dezembro de 2011.

Cremer M. 2007. Ecologia e conservação de populações simpátricas de pequenos cetáceos em ambiente estuarino no sul do Brasil. $\mathrm{Ph} . \mathrm{D}$. thesis. Universidade Federal do Paraná, Curitiba. 212 pp.

Cremer M.J., Simões-Lopes P.C. 2008. Distribution, abundance and density estimates of franciscana, Pontoporia blainvillei (Cetacea: Pontoporiidae), in Babitonga Bay, southern Brazil. Rev. Bras. Zool. 25: 397-402. http://dx.doi.org/10.1590/S0101-81752008000300003

Cremer M.J., Hardt F.A.S., Tonello A.J. Jr., et al. 2011. Distribution and Status of the Guiana Dolphin Sotalia guianensis (Cetacea, Delphinidae) Population in Babitonga Bay, Southern Brazil. Zool. Stud. 50: 327-337.

Cremer M.J., Pinheiro P.C., Simões-Lopes P.C. 2012. Prey consumed by Guiana dolphin Sotalia guianensis (Cetacea, Delphinidae) and Franciscana dolphin Pontoporia blainvillei (Cetacea, Pontoporiidae) in an estuarine environment in southern Brazil. Iheringia (Série Zoologia). 102: 131137. http://dx.doi.org/10.1590/S0073-47212012000200003

Crespo E.A., Harris G., González R. 1998. Group size and distributional range of the franciscana, Pontoporia blainvillei. Mar. Mamm. Sci. 14: 845-849. http://dx.doi.org/10.1111/j.1748-7692.1998.tb00768.x

Daura-Jorge F.G., Wedekin L.L., Simões-Lopes P.C. 2004. Variação sazonal na intensidade dos deslocamentos do boto-cinza, Sotalia guianensis (Cetacea: Delphinidae), na Baía Norte da Ilha de Santa Catarina. Biotemas. 17: 203-216.

De Boer M.N., Simmonds M.P., Reijnders P.J.H., et al. 2014. The Influence of Topographic and Dynamic Cyclic Variables on the Distribution of Small Cetaceans in a Shallow Coastal System. PLoS ONE 9: e86331. http://dx.doi.org/10.1371/journal.pone.0086331

Dunning J.B. Jr., Groom M.J., Pulliam H.R. 2006. Species and landscape approaches to conservation. In: Groom M.J., Meffe G.K., Carroll C.R. (eds). Principles of conservation biology. Sinauer Associates. Sunderland. pp. 419-466.

Fury C.A., Harrison P.L. 2011. Seasonal variation and tidal influences on the use of two Australian estuaries by bottlenose dolphins (Tursiops aduncus). Estuar. Coast. Shelf. S. 93: 389-395. http://dx.doi.org/10.1016/j.ecss.2011.05.003

Gibson R.N. 2003. Go with the flow: tidal migration in marine animals. In: Jones M.B., Ingólfsson A., Ólafsson E., et al. (eds). Migrations and Dispersal of Marine Organisms. Hydrobiologia 503: $153-161$.

http://dx.doi.org/10.1007/978-94-017-2276-6_17

Goodwin L. 2008. Diurnal and Tidal Variations in Habitat Use of the Harbour Porpoise (Phocoena phocoena) in Southwest Brit- ain. Aquat. Mamm. 34: 44-53. http://dx.doi.org/10.1578/AM.34.1.2008.44

Gratwicke B., Speight M. 2005. The relationship between fish species richness, abundance and habitat complexity in a range of shallow tropical marine habitats. J. Fish Biol. 66: 650-667. http://dx.doi.org/10.1111/j.0022-1112.2005.00629.x

Hardt F., Cremer M.J., Tonello A.J., et al. 2010. Residence patterns of the guiana dolphin Sotalia guianensis in Babitonga Bay, south coast of Brazil. Lat. Am. J. Aquat. Mamm. 8: 117-121. http://dx.doi.org/10.5597/lajam00160

Harrison I.J. 2002. Mugilidae: mullets. In: Carpenter K. (ed.). The living marine resources of the Western Central Atlantic. Vol. 2. Bony fishes part 1 (Acipenseridae to Grammatidae). FAO Species Identification Guide for Fisheries purposes. Rome, FAO. pp 1071-1085.

Hastie G.D., Wilson B., Wilson L.J., et al. 2004. Functional mechanisms underlying cetacean distribution patterns: hotspots for bottlenose dolphins are linked to foraging. Mar. Biol. 144: 397-403. http://dx.doi.org/10.1007/s00227-003-1195-4

Hooge P.M., Eichenlaub B. 1997. Animal Movement Extension to ArcView (version 1.1). Alaska Biological Science Center, Geological Survey. Anchorage - AK, USA.

IBAMA - Instituto Brasileiro do Meio Ambiente e dos Recursos Naturais Renováveis. 1998. Proteção e controle de ecossistemas costeiros: manguezal da Baía da Babitonga. Coleção Meio Ambiente: Série Estudos - Pesca. Brasília: Edições IBAMA, $146 \mathrm{pp}$.

Ijsseldijk L.L., Camphuysen K.C.J., Nauw J.J., et al. 2015. Going with the flow: Tidal influence na the occurrence of the harbour porpoise (Phocoena phocoena) in the Marsdiep área, The Netherlands. Neth. J. Sea Res. 103: 129-137. http://dx.doi.org/10.1016/j.seares.2015.07.010

Ingram S.N., Rogan E. 2002. Identifying critical areas and habitats preferences bottlenose dolphins Tursiops truncatus. Mar. Ecol. Prog. Ser. 244: 247-255. http://dx.doi.org/10.3354/meps244247

Krebs C.J. 2008. Ecology: The experimental analysis of distribution and abundance. Benjamin Cummings Press, San Francisco, 688 pp.

Laver P.N. 2005. Kernel Home Range Estimation for ArcGIS, using VBA and Arc Objects. User Manual, Beta 2. 62 pp.

Lin T., Chou L., Akamatsu T. 2013. Tidal influences on the habitat use of Indo-Pacific humpback dolphins in an estuary. Mar. Biol. 160: $1353-1363$ http://dx.doi.org/10.1007/s00227-013-2187-7

Lodi L.F. 2003. Seleção e uso do habitat pelo boto-cinza, Sotalia guianensis (van Bénéden, 1864) (Cetacea, Delphinidae), na Baía de Paraty, Estado do Rio de Janeiro. Bioikos 17: 5-20.

Louzada C.N. 2014. Características das estratégias de pesca do boto-cinza (Sotalia guianensis) em diferentes regiões do complexo estuarino-lagunar de cananéia. Ph. D. thesis (Master). Universidade Federal do Paraná. Curitiba.

MMA - Ministério do Meio Ambiente 2014. Lista Oficial de Espécies Brasileiras Ameaçadas de Extinção. Ministério do Meio Ambiente - Governo Federal (Brasil). MMA / SBF. Brasília.

Mann J. 1999. Behavioral sampling methods for cetaceans: a review and critique. Mar. Mamm. Sci. 15: 102-122. http://dx.doi.org/10.1111/j.1748-7692.1999.tb00784.x

Mclusky D.S., Elliott M. 2004. The Estuarine Ecosystem: Ecology, Threats and Management. 3rd Edition, Oxford University Press, $216 \mathrm{pp}$. http://dx.doi.org/10.1093/acprof:oso/9780198525080.001.0001

Mellinger D.K., Stafford K.M., Moore S.E., et al. 2007. An Overview of Fixed Passive Acoustic Observation Methods for Cetaceans. Oceanography 20: 36-45. http://dx.doi.org/10.5670/oceanog. 2007.03

Mendes S., Turrell W., Lütkebohle T., et al. 2002. Influence of the tidal cycle and a tidal intrusion front on the spatio-temporal distribution of coastal bottlenose dolphins. Mar. Ecol. Prog. Ser. 239: 221-229. http://dx.doi.org/10.3354/meps239221

Paitach R.L. 2015. Ecologia alimentar e espacial da toninha (Pontoporia blainvillei) e do boto-cinza (Sotalia guianensis) na Baía da Babitonga, Sul do Brasil. Ph.D. thesis (Master of Ecology), Federal University of Santa Catarina, Florianopolis, Santa Catarina, Brazil. 142 pp.

Parsons E.C.M. 1998. The behaviour of Hong Kong's resident cetaceans: The Indo-Pacific humpbacked dolphin and the finless porpoise. Aquat. Mamm. 24: 91-110. 
Perry G., Pianka E.E.R. 1997. Animal foraging: past, present and future. Tree 12: 360-364. http://dx.doi.org/10.1016/S0169-5347(97)01097-5

Powell R.A. 2000. Animal home ranges and territories and home range estimators. In: Boitani L. and Fuller T.K. (eds). Research techniques in animal ecology: controversies and consequences. Columbia University Press, New York. pp. 65-110.

R Development Core Team. 2014. R: A language and environment for statistical computing. R Foundation for Statistical Computing. Vienna, Austria. ISBN 3-900051-07-0, http://www.R-project.org/

Reeves R., Dalebout M., Jefferson T.A., et al. 2012. Pontoporia blainvillei. The IUCN Red List of Threatened Species. Version 2014.3.

Reis-Filho J.A., Barros F., Nunes J.A.C.C., et al. 2011. Moon and tide effects on fish capture in a tropical tidal flat. J. Mar. Biol. Ass. U.K. 91: 735-743. http://dx.doi.org/10.1017/S0025315410001955

Robins C.R, Ray G.C. 1986. A field guide to Atlantic coast fishes of North America. Houghton Mifflin Company, Boston, USA. 354 p.

Santos U.A., Alvarez M.R., Schilling A.C., et al. 2010. Spatial distribution and activities of the estuarine dolphin Sotalia guianensis (van Bénéden, 1864) (Cetacea, Delphinidae) in Pontal Bay, Ilhéus, Bahia, Brazil. Biota Neotrop. 10: 67-73. http://dx.doi.org/10.1590/S1676-06032010000200007

Scott M.D., Wells R.S., Irvine A.B. 1990. A long-term study of bottlenose dolphins on the west coast of Floridain. In: Leatherwood S. and Reeves R.R. (eds). The bottlenose dolphin. Academic Press, San Diego, pp. 235-244. http://dx.doi.org/10.1016/B978-0-12-440280-5.50015-9

Secchi E. 2012. Sotalia guianensis. The IUCN Red List of Threatened Species. Version 2012.2.

Shane S.H. 1990. Behavior and ecology of the bottlenose dolphin at Sanibel Island, Florida. In: Leatherwood S. and Reeves R.R. (eds). The bottlenose dolphin. Academic Press, San Diego, pp 369-386.

http://dx.doi.org/10.1016/B978-0-12-440280-5.50016-0
Siciliano S. 1994. Review of small cetaceans and fishery interactions in coastal waters of Brazil. Report of the Internatinal Whaling Commission (special issue), Rio de Janeiro, 15: 241-250.

Simões-Lopes P.C. 1988. Ocorrência de uma população de Sotalia fluviatilis, Gervais 1853, (Cetacea, Dephinidae) no limite sul de sua distribuição, Santa Catarina, Brasil. Biotemas 1: 57-62.

Souto A., Araújo J.P., Geise L., et al. 2006. The surface behaviour of the estuarine dolphin in Baía dos Golfinhos, RN, Brazil: a field and comparative study. Rev. Brasileira de Zoociências 8: 183-192.

Squires N., Ball K.H., Bennett K., et al. 2014. Using passive acoustics and shorebased surveys to investigate the distribution of small odontocetes in nearshore waters around lundy. J. Lundy Field Soc., 4: 39-56.

Truccolo E.C., Schettini C.A.F. 1999. Marés astronômicas na Baía da Babitonga, SC. Notas Técnicas Facimar, 3: 57-66.

Underwood A.J. 1981. Experiments in ecology: Their logical design and interpretation using analysis of variance, Cambridge Univ. Press, Cambridge. 504 pp.

Vieira C.V., Horn-Filho N.O., Bonetti C.V.D.H.C. et al. 2008. Caracterização Morfosedimentar e Setorização do Complexo Estuarino da Baía da Babitonga/SC. Boletim Paranaense de Geociências. 62-63: 85-105. http://dx.doi.org/10.5380/geo.v62i0.12783

Wedekin L.L., Daura-Jorge F.G., Piacentini V.Q. et al. 2007. Seasonal variations in spatial usage by the estuarine dolphin, Sotalia guianensis (van Bénéden, 1864) (Cetacea; Delphinidae) at its southern limit of distribution. Braz. J. Biol. 67: 1-8. http://dx.doi.org/10.1590/S1519-69842007000100002

Wedekin L.L., Daura-Jorge F.G., Simões-Lopes P.C. 2010. Habitat preferences of Guiana dolphins, Sotalia guianensis (Cetacea: Delphinidae), in Norte Bay, southern Brazil. J. Mar. Biol. Ass. U.K. 90: 1561-1570. http://dx.doi.org/10.1017/S0025315410001414

Zar J.H. 1999. Biostatistical Analysis. 4nd edn. Prentice Hall. New Jersey. 